\title{
Goodbye and Good Luck
}

Correspondence for Reference \& User Services Quarterly should be addressed to Editor Diane Zabel, Schreyer Business Library, The Pennsylvania State University, 309 Paterno Library, University Park, PA 16802; e-mail:dxz2@psu.edu. his is my last issue as editor of Reference \& User Services Quarterly (RUSQ). The past six years have been the most rewarding of my professional career. I have had the good fortune of being guided by an exemplary editorial advisory board, dedicated column and book review editors, a supportive board of directors, engaged readers, and exceptional staff in ALA Production Services and the RUSA office. In particular, I want to acknowledge Tim Clifford, our amazing production editor, and Susan Hornung (RUSA's executive director). Dozens of occasional referees (along with the members of the RUSQ editorial advisory board) have generously volunteered their time and expertise to help authors produce their best work.

I am delighted that Barry Trott has been appointed incoming editor of RUSQ. Barry became editor-designate on February 1,2012 , and will assume the position of editor on July 1,2012 . I know that the journal will be in very good hands. Barry is digital services director at Williamsburg Regional Library. For the past seven years he has been editor of RUSQ's Readers' Advisory column. Barry is also the series editor for Read On ...., the readers' advisory genre series published by Libraries Unlimited. He also contributes content to the NoveList readers' advisory database. Barry is also a prolific author. In addition to his numerous publications, he is a frequent presenter at conferences. Additionally, he serves as an adjunct professor at Catholic University's Graduate School of Library and Information Science. Barry also has extensive contacts in the field, having served as president of RUSA. Barry has also been recognized for his outstanding work in adult services. He is the 2007 recipient of the ALA/RUSA Margaret E. Monroe Library Adult Services Award.

Barry is a great match for the journal. He has terrific ideas for attracting readership and for building the journal online. I can hardly wait to see how the journal evolves under his creative direction. I wish Barry the best of luck and know that he too will find the editorship a gratifying experience. 